\title{
An Empirical Analysis Of The Effects Of Auditor Time Budget Pressure And Time Deadline Pressure
}

Loren Margheim, (E-mail: margheim@SanDiego.edu), University of San Diego Tim Kelley, (E-mail: tkelley@SanDiego.edu), University of San Diego

Diane Pattison, (E-mail: pattison@SanDiego.edu), University of San Diego

\begin{abstract}
This study utilized a case method approach to examine the impact of time budget pressure and time deadline pressure on auditor perceptions of stress, key organizational behavior measures, and cognitive problems. The results indicate that increases in both types of time pressures will cause increased stress perceptions by both senior and staff auditors in a nonadditive manner. Specifically, examination of the case means suggested that stress levels are highly affected when one of the two types of time pressure are encountered, with little additional increase in stress when the other type of time pressure is encountered simultaneously. However, both types of time pressure were found to have individual, additive effects on the auditors' organizational behavior measures and, to a lesser extent, on the cognitive problems examined in the study. Overall, the results of the study indicate that time pressure cannot be examined generally; rather, it must be decomposed into the individual types of time pressure (time budget or time deadline) to properly understand the effects the specific time pressure is having on auditors.
\end{abstract}

\section{INTRODUCTION}

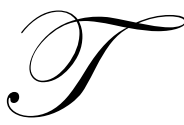

he Report of the Commission on Auditors Responsibilities (AICPA 1978), Solomon and Brown (1992), DeZoort and Lord (1997), and Kelley et al. (1999) note that auditor time pressure comes in two distinct forms -- time budget pressure and time deadline pressure. However, prior accounting research has generally failed to differentiate between these two types of time pressure. In addition, while Kelley et al. (1999) surveyed auditors about time budget and time deadline pressure, auditing research has never assessed what interrelations the two time pressures have on auditor behavior. This study employs the case method and extends prior research by examining both types of time pressure concurrently to assess any individual and/or joint impact they might have on auditor behavior.

In general, audit time budget pressure occurs when an audit firm allocates (i.e., budgets) a scarce number of audit hours to be used by auditors to complete specified audit procedures. On the other hand, time deadline pressure occurs when a specific point in time (i.e., a deadline) for task completion is specified and it is difficult to complete the required work by the deadline.

This case study manipulated both time budget pressure and time deadline pressure at moderate and high levels to determine their individual and joint impacts on 12 individual stressor effects grouped into three categories, including (1) a subjective stress measure, (2) organizational behavior measures (e.g., auditor effectiveness, efficiency, and likelihood of engaging in dysfunctional behaviors), and (3) cognitive problems (e.g., likelihood of careless mistakes). The research questions examined anticipated that the two types of time pressure would have independent, additive affects on the stressor effects. 
The remainder of the paper includes a discussion of the prior research, the study's research questions, the method, statistical analyses and results, and summary of results. The paper concludes with some suggestions for future research.

\section{PRIOR RESEARCH}

\section{Time Budget Pressure}

Budget related time pressure can only occur when the budgeted amount of time is less than total available time and the auditor has the ability to respond to the pressure by completing the work on their personal time and underreporting the amount of time spent on the audit task. Prior research examining auditor time budget pressure has generally been performed using surveys or case studies (e.g., Rhode 1978; Kelley and Seiler 1982; Lightner, Adams and Lightner 1982; Alderman and Deitrick 1982; Margheim and Pany 1986; Cook and Kelley 1988; Kelley and Margheim 1990; Cook and Kelley 1991; Raghunathan 1991; Waggoner and Cashell 1991; Malone and Roberts 1996; Otley and Pierce 1996; Kelley et al. 1999; and Houston 1999). In general, many of these studies have indicated that audit time budget pressure has been increasing over time. In addition, the research suggests that audit effectiveness may be negatively affected as a result of auditors engaging in dysfunctional behaviors (e.g., premature audit program sign-offs and underreporting of chargeable time) in order to meet their time budgets. DeZoort and Lord (1997) provides a comprehensive review of prior time budget and time deadline pressure related research in accounting.

\section{Time Deadline Pressure}

Time deadline pressure occurs when auditors are pressured to complete audit tasks in the total available time before a deadline for completion of the task is reached. In this case, the task completion point is established rather than the number of hours to be used in completing the task.

Prior research examining auditor time deadline pressures has generally consisted of experiments where auditors were given a task to perform and the amount of available time to complete the task was varied across subjects. For example, McDaniel (1990) found that as the time deadline pressure utilized in her study increased, auditors' job effectiveness decreased and their efficiency increased. In contrast, research by Choo (1995) and Glover (1997) suggested that as time deadline pressure increases from low to moderate levels, auditor judgment performance improves due to the reduction in the usage of nondiagnostic (i.e., irrelevant) cues. However, Choo indicates that as deadline pressure increases to higher levels, performance declines because relevant cues are also ignored.

\section{RESEARCH QUESTIONS}

Since prior research has not empirically examined the interrelationship between time budget pressure and time deadline pressure, we cannot develop specific hypotheses based on prior research results. Instead, we have developed three research questions that are exploratory in nature based on our personal experiences and discussions with practicing auditors. Based on these discussions we believe that the two types of time pressure are created by fundamentally different sets of circumstances and will, thus, have independent effects on auditors and their behaviors.

Specifically, our research questions suggest that time budget pressure and time deadline pressure will have "additive" effects on the stressor effects. An additive effect would occur when there is no interaction between the two types of time pressures and examination of case means indicates that the negative consequences of each of the time pressure types can be added together to determine the impact of having high levels of both types of time pressure present simultaneously. Therefore, the research questions examined in the study are as follows: 


\section{Research Question 1:}

Time budget pressure and time deadline pressure will have individual main effects which are additive (i.e., no interaction) on senior and staff auditor perceived stress levels.

\section{Research Question 2:}

Time budget pressure and time deadline pressure will have individual main effects which are additive (i.e., no interaction) on perceived senior and staff auditor organizational behavior measures.

\section{Research Question 3:}

Time budget pressure and time deadline pressure will have individual main effects which are additive (i.e., no interaction) on perceived senior and staff auditor cognitive problems.

\section{METHOD}

Task

A case describing an upcoming audit of a computer software company was developed for use in the study. Time budget pressure and time deadline pressure served as the independent variables and were manipulated at moderate and high levels. The independent variables were fully crossed resulting in four versions of the case.

Both Big-4 and Non Big-4 senior and staff auditors were utilized as subjects. ${ }^{1}$ A between-subjects design was used where each auditor subject received only one of the four versions of the case. Each subject was asked to evaluate the case materials and to indicate the likelihood that the hypothetical auditors described in the case would experience stress and would engage in, or experience, the various organizational behaviors and cognitive problems. Specifically, each case included:

a. Background information on the audit, including financial statements.

b. Description of the audit time pressures on the audit (i.e., independent variables). This consisted of:

one of two possible levels of time budget pressure (i.e., moderate or high), and one of two possible levels of time deadline pressure (i.e., moderate or high).

c. Subject responses consisting of:

assessments of the degree of stress the senior auditor and staff auditor in the case would likely encounter on the audit,

assessments of the probability that the auditors would engage in, or experience, specified organizational behaviors and cognitive problems,

manipulation check questions, and

subjects' demographic data.

\section{Case Materials}

The case materials involved an audit of a small software company where audit field work was about to begin. In general, the background information describes a growing company (e.g., 16\% earnings growth in the last year) that was stable with no financial problems that should have distracted the respondent's attention from the manipulated independent variables.

Specifically, the software company was described as a publicly owned company that has been audited by the same accounting firm since going public three years ago. The audit normally takes four weeks to complete (start 
of field work to issuance of audited financial statements) and requires one senior auditor and one staff auditor. Fortunately, both the senior auditor and staff auditor from the prior year's audit have been reassigned to the current audit.

Audited financial statements from the prior year and preliminary, unaudited financial statements for the current year were also provided. In addition, several financial ratios for the two years were computed and presented along with applicable industry averages. The ratios were stable over the two years at values close to the industry averages.

\section{Subjects}

Three Big-4 CPA firms and two non Big-4 CPA firms agreed to participate in the study. The two non Big4 firms were medium to large size firms with offices nationwide. The firms agreed to supply a representative at selected offices who would distribute the case instruments to senior and staff auditor mailboxes. In addition, an appropriate individual from the firms (e.g., office partner) supplied a cover letter encouraging participation.

The firm representatives received two sets of cases -- one set to be distributed to senior auditors and another set for staff auditors. Due to the sensitivity of some of the response questions, subjects were asked to mail their responses directly to the researchers using an attached self-addressed stamped envelope.

A total of 460 case instruments were distributed (i.e., 115 of each of the four case instrument versions). A total of 135 responses were returned which represented a twenty-nine percent response rate, which is typical for this type of case study (e.g., Margheim and Pany 1986). Of these responses, 70 came from Big-4 auditors and 65 came from non Big-4 auditors. In addition, 61 came from senior auditors and 74 came from staff auditors.

\section{INDEPENDENT VARIABLES}

\section{Time Budget Pressure}

As previously discussed, time budget pressure relates to the pressure experienced when trying to complete audit work within the budgeted audit time established by the auditing firm. Two time budget pressure levels (moderate and high) were developed for use in the case. As noted below, these levels were described to provide realistic levels that were not extreme.

The moderate time budget pressure level indicated that the audit manager had recently completed the time budget for the current year and that it was almost identical to the prior year's budget, with the same overall total budgeted audit hours. The audit fee was noted to be approximately the same as the prior year's fee. However, the case noted that both the senior auditor and staff auditor felt that the prior year's time budget was only attainable with considerable effort from both of them.

The high time budget pressure level indicated that the audit manager had completed the time budget for the current year and it contained approximately $20 \%$ less budgeted audited time than in the prior year. It was noted that the cut in budgeted audit time was a result of a $20 \%$ reduction in the audit fee that the software company had negotiated since the prior year's audit. This reduction level was based on pilot testing of the instrument and the results of Bedard and Wright (1994) which suggest this percentage reduction would create a reasonable high level of time budget pressure while remaining realistic.

\section{Time Deadline Pressure}

As previously discussed, time deadline pressures are caused by the need to complete an audit task in the total available time prior to a deadline. While deadline pressures can be caused by factors internal or external to the audit firm, we manipulated a client imposed deadline to create moderate and high levels of time deadline pressure. 
Several things were held constant in all (i.e., both moderate and high level) cases that were directly related to the time deadline manipulation. First, all cases noted that the software company announced just a few days prior to the start of the audit field work that they were engaged in merger discussions. Second, all cases noted that the merger discussions would not result in any renegotiation of audit fees. Third, all cases indicated that, except for the due date to deliver the audited financials to the client, there were no other time deadlines that the auditors had to meet for this audit. Finally, all cases indicated that the start of the audit field work could not be moved up in response to the merger discussions. As discussed below, these items were held constant in order to establish a situation where a client imposed deadline (i.e., the due date for the audited financials) could be effectively manipulated, holding other factors constant.

In the moderate time deadline pressure situation, the case indicated that the merger discussions would not have a direct effect on the previously set due date for the final audited financial statements to be submitted to the company. That deadline was consistent with the prior year's deadline. This moderate time deadline level was developed so that it would appear to subjects that the deadline could be met, but with some considerable effort.

In the high time deadline pressure situation, the company announced that as a result of the merger discussions the due date for the final audited financial statements needed to be moved up. Overall, the auditors would lose approximately $20 \%$ of the total available time between the start of fieldwork and the newly revised due date for the final audited financial statements. This percentage reduction was based on pilot testing of the instrument and the desire to have a percentage reduction in time deadline pressure that was identical to that used for time budget pressure.

\section{DEPENDENT VARIABLES}

The dependent variables in the current study include: (1) a subjective stress measure, (2) organizational behavior measures, and (3) cognitive problems.

\section{Subjective Stress Measure}

Subjects were to asked to evaluate the case materials and to indicate the extent of overall stress they believed would be experienced by the hypothetical senior and the overall stress experienced by the hypothetical staff auditor, respectively. The case materials indicated that the respondent should assume that no additional staff could be assigned to the audit and that no adjustments to the existing audit times could be made. Subjects responded on a seven-point Likert scales ranging from "no stress" at the low end of the scale to "extreme stress" at the high end of the scale (see Table 2 for the complete scale).

Senior auditor subjects were asked to assess both the senior and the staff auditors' stress levels because they have served in both positions and should clearly have the experience to assess the stress each auditor in the case would likely experience. Staff auditor subjects were also asked to provide stress assessments for both the senior and staff auditors' stress levels even though they have not served as senior auditors. However, we believe that staff auditors ascertain rather quickly the type of situations that cause their seniors to experience stress and were qualified to give overall stress assessments for both senior and staff auditors.

\section{Organizational Behavior Measures}

Organizational behavior measures examined were classified as either auditor performance measures or auditor dysfunctional behavior measures. Specifically, two auditor performance measures were utilized - auditor effectiveness and efficiency. Respondents were asked to give their assessed probability that the hypothetical senior auditor and staff auditor would "be highly" effective and efficient, respectively, on this audit. Probability assessments could range from zero to one hundred percent.

Six dysfunctional behaviors were utilized and are shown in Table 4. These behaviors were adopted from prior research (see Kelley and Margheim 1990; and Malone and Roberts 1996). Respondents were also asked to give 
their assessed probabilities that the senior auditor or staff auditor would engage, at least once, during the audit in each of the six different dysfunctional behaviors (e.g., prematurely signing off audit program steps).

Senior auditor subjects were asked to provide probability assessments to these organizational behavior measures for both the senior and staff auditor in the case. On the other hand, the staff auditor subjects were only asked to give their probability assessments relative to the staff auditor in the case, since we believed they would be too inexperienced to provide reliable responses related to these very specific senior auditor behaviors.

\section{Cognitive Problems}

In general, the cognitive problems in this study related to situations where time pressure might cause a faulty cognition that leads to some type of dysfunctional involuntary action on the part of the auditor (See Cox, 1978 and Collins and Killough, 1992). While cognitive problem measures have received little attention in auditing research, Haskins et al. (1990) found that stress did have adverse affects on auditor anxiety and depression levels. Therefore, it is likely time related pressures would also have adverse impacts on auditors' cognitive functions.

Three cognitive problems were used in this study consisting of making careless mistakes, mentally blocking out important information, and encountering problems differentiating between serious and trivial problems. As with the organizational behaviors, respondents were asked to indicate the probability that the senior and/or staff auditor would have experienced each of these cognitive problems during the audit.

\section{STATISTICAL ANALYSES AND RESULTS}

The three research questions were tested using analysis of variance (ANOVA) and multivariate analysis of variance (MANOVA) testing procedures. ${ }^{2}$ The respondents' assessments of stress, organizational behavior measure probabilities, and cognitive measure probabilities served as the dependent variables for each of the three analyses. Time budget pressure and time deadline pressure served as the independent variables.

\section{Manipulation Check Results}

After completing their responses regarding senior and/or staff auditor behaviors, the subjects were asked to indicate on a seven-point Likert scale (see Table 2 for a similar scale related to stress) the extent of time budget and time deadline pressure that they believed the senior and staff auditor in the case experienced. Means are shown below.

\section{Time Budget Pressure}

\begin{tabular}{|c|c|}
\hline Moderate & High \\
\hline 4.5 & 6.0 \\
\hline 4.3 & 5.5 \\
\hline
\end{tabular}

\section{Time Deadline Pressure}

\begin{tabular}{|c|c|}
\hline Moderate & High \\
\hline 4.6 & 6.4 \\
\hline 4.3 & 5.8 \\
\hline
\end{tabular}

These differences in means were all statistically significant indicating that the respondents perceived the levels of the respective moderate and high time pressure levels as intended for both the hypothetical senior and staff auditors in the case.

\section{Subjective Stress Results}

The results of the ANOVAs on the expected senior auditor and staff auditor stress levels are shown in Table 1. The results indicate that time budget pressure and time deadline pressure had significant main effects on both the perceived senior and staff auditor stress levels. However, contrary to Research Question 1, the interactions were significant for both the hypothetical senior and staff auditor indicating that the effects of the two types of time pressures were not additive. 
Table 2 shows the main effect means for each type of time pressure and the individual case means. The main effect means indicate that the respondents believed that both the hypothetical senior and staff auditor would experience increased stress when they were under high time budget or high time deadline conditions. Interestingly, the hypothetical senior auditor stress means were all higher than the staff auditor means.

Examination of the case means does not provide a clear interpretation of the significant time budget/time deadline interactions. However, it does appear that stress levels jumped considerably when a high level of either type of time pressure was present and that stress levels did not increase at the same rate when a second type of high time pressure was added. This suggests having a high level of either time pressure may produce the bulk of the auditors' perceived stress.

\section{ORGANIZATIONAL BEHAVIOR MEASURES RESULTS}

MANOVAs were performed on the eight senior auditor and the eight staff auditor organizational behavior measures, respectively, and the results are shown in Table 3. The results of both the hypothetical senior auditor MANOVA and hypothetical staff auditor MANOVA indicate that the time budget pressure and time deadline pressure variables produced significant main effects while the interactions between the two types of time pressures were not significant. These results seem to support our Research Question 2 which suggested that the two time pressures would have individual, additive effects on the organizational behavior measures of both senior and staff auditors.

\section{Individual Senior Auditor Organizational Behavior Measures}

Table 4 shows the main effect means for each type of time pressure and the individual case means for the eight senior auditor organizational behavior measures. ANOVA results for each measure are also included.

Overall, time budget pressure significantly affected six of the eight measures, including five of the dysfunctional behavior measures. Time deadline pressure significantly affected four of the eight measures, including only two of the dysfunctional behavior measures. Significant differences were all in the directions anticipated. These results seem to suggest that time budget pressure may cause a wider range of dysfunctional behaviors by senior auditors than time deadline pressure. These results are similar to those found in a survey of auditor opinions by Kelley et al. (1999).

The time budget/time deadline interactions were not significant in any of the eight individual ANOVAs indicating that the two time pressures had additive effects on each of the senior organizational behaviors. Examination of the individual case means also suggests that the two types of time pressure had additive effects, particularly for those measures where both types of time pressures had individual main effects. For example, the mean probability of having a highly effective senior dropped to $48 \%$ when high levels of both time pressures were present versus mean probabilities $76 \%$ and $74 \%$ when time deadline and time budget pressure, respectively, were only individually at high levels and $87 \%$ when both time pressures were at moderate levels.

\section{Individual Staff Auditor Organizational Behavior Measures}

Table 5 shows similar individual staff auditor organizational behavior measure means and ANOVA results for each measure. Overall, time budget pressure significantly affected six of the eight measures, including five of the dysfunctional behavior measures. Time deadline pressure significantly affected seven of the eight measures, including five of the dysfunctional behavior measures. Again, all significant differences were in the directions anticipated. Overall, these staff auditor results are similar to those for the senior auditor, except that they suggest that staff auditors might be more likely than seniors to respond to increased time deadline pressure by engaging in dysfunctional behaviors. Similar to the senior auditor results, the time budget/time deadline interactions were not significant in any of the eight individual ANOVAs indicating that the two time pressures had additive effects on each of the staff organizational behaviors. 


\section{COGNITIVE PROBLEMS RESULTS}

The results of MANOVAs on the expected senior auditor and staff auditor cognitive problems are shown in Table 6. The results indicate that time budget pressure and time deadline pressure had significant main effects on perceived staff auditor cognitive problems. However, only time budget pressure had a significant main effect for senior auditors. Interactions in both MANOVAs were nonsignificant.

Table 7 shows the main effect means for each type of time pressure and the individual case means for senior auditors. The results indicate that time budget pressure significantly affected two of the three cognitive problems while time deadline pressure only affected one of the three. As with the dysfunctional behavior measures, these results might suggest that time budget pressure might have more serious consequences on senior auditors.

Table 8 shows the main effect means and the individual case means for staff auditors. The results indicate that time budget pressure significantly affected all three cognitive problems while time deadline pressure only affected two of the problems.

The time budget/time deadline interactions were not significant in any of the ANOVAs performed on the individual senior and staff auditor cognitive problems. The nonsignificant interactions suggest that the two time pressures have additive effects. These results tend to support Research Question 3. However, the senior auditor results are weaker given the overall insignificant time deadline pressure main effect.

\section{SUMMARY OF RESULTS}

This study examined the impact of time budget pressure and time deadline pressure on auditor subjective stress perceptions, key organizational behavior measures, and cognitive problems. Overall, the results indicated that increases in both types of time pressures would cause increased stress perceptions by senior and staff auditors. However, subjective stress perceptions were affected by an interaction between the two types of time pressure. Examination of the means suggested that stress levels are highly affected when one of the two types of time pressure is encountered, with little additional increase in stress when the other time pressure is encountered at the same time.

Both types of time pressure were found to have individual, additive effects on the auditors' organizational behavior measures examined in the study. Overall, increased levels of each type of time pressure had negative effects on the occurrence of auditor dysfunctional behaviors without any interactions between the type types of time pressure.

The impact of the two time pressures on cognitive problems depended on the level of the auditor being examined. Only time budget pressure was found to have a significant effect on senior auditors' cognitive problems, while both types of time pressures had significant effects on perceived staff auditor cognitive problems. Again the effects of the two time pressures appeared to be additive for both the senior and staff auditor. Overall, the results of this study indicate that time pressure cannot be examined generally; rather, it must be decomposed into the individual types of time pressure (time budget or time deadline) to properly understand the effects the specific time pressure is having on auditors.

\section{SUGGESTIONS FOR FUTURE RESEARCH}

The results of this study clearly suggest that additional research examining the effects of time pressure on auditors needs to be performed. Prior research has often relied upon a general definition of time pressure and in reviewing the prior research it has often been necessary to review the exact process that was used in varying time pressure to determine if the research was oriented toward examining time budget or time deadline pressure.

Additionally, the results seem to suggest that time budget pressure has a bigger impact on senior auditor organizational behaviors and cognitive problems than does time deadline pressure. Further research is clearly needed to examine when time budget pressure versus time deadline pressure has the most negative effects on the 
different levels auditors (e.g., staff versus seniors) and what auditing firms might do to mitigate the effects of the two specific types of time pressure.

Additional research is needed that focuses on the effects of the two types of time pressure on involuntary, cognitive problems. The results of this study are limited in that only three cognitive problems were examined and the results were mixed. However, the results do tend to suggest that the two types of time pressure will have differing affects on auditor cognitive problems.

Finally, the accounting profession has undergone a great deal of turmoil since the Enron and WorldCom accounting scandals and the subsequent passage of the Sarbanes/Oxley reform legislation (See Covaleski, 2002; Klein, 2002). Audit firms' approaches to audit time budgeting and time deadlines may undergo substantial change due to these events. Future research should reexamine the occurrence and effects of time budgets and time deadlines after the reform legislation has been fully implemented.

\section{ENDNOTES}

1 Data for the study was gathered during the Big-5 period. The terminology in the paper has been updated to reflect the current Big-4 environment.

2 The type of firm of the respondent (Big-4 or non Big-4) and the position of the respondent (senior or staff auditor) were originally used as covariates in the statistical analyses. However, their impact was so limited that they were dropped from the analyses shown in the paper. In no instance did either of these potential covariates affect the statistical significance or the interrelationship between the two types of time pressure examined in the study.

\section{REFERENCES}

1. Alderman, C.W., and J.W. Deitrick, “Auditors' Perceptions of Time Budget Pressures and Premature Signoffs: A Replication and Extension," Auditing: A Journal of Practice and Theory, pp. 53-68, Winter 1982.

2. American Institute of Certified Public Accountants (AICPA), The Commission on Auditors' Responsibilities: Report, Conclusions, and Recommendations. New York: AICPA, 1987

3. Bedard, J., and A. Wright, "The Functionality of Decision Heuristics: Reliance on Prior Audit Adjustments in Evidence Planning," Behavioral Research in Accounting, Vol. 6, pp. 62-89, 1994 Supplement.

4. Choo, F., "Job Stress, Job Performance, and Auditor Personality Characteristics," Auditing: A Journal of Practice and Theory," pp. 667-685, Spring 1986.

5. Choo, F., “Auditors' Judgment Performance Under Stress: A Test of the Predicted Relationship By Three Theoretical Models," Journal of Accounting, Auditing \& Finance," pp. 611-641, Summer 1995.

6. Collins, K., and L. Killough, "An Empirical Examination of Stress in Public Accounting," Accounting, Organizations, and Society," Vol. 17, No. 6, pp. 535-547, 1992.

7. Cook, E., and T. Kelley, “Auditor Stress and Time Budget,” The CPA Journal, pp. 83-86, July 1988.

8. Cook, E., and T. Kelley, "An International Comparison of Audit Time-Budget Pressures: The United States and New Zealand," The Women CPA, pp. 25-30, Spring 1991.

9. Covaleski, J., "Firms Brace for New Government Audit Regulations," Accounting Today, Vol. 16, No. 21, p. 1, Nov. 25 - Dec. 15, 2002.

10. Cox, T., Stress, London: Macmillan, 1978.

11. DeZoort, F., and A. Lord, "A Review and Synthesis of Pressure Effects Research in Accounting," Journal of Accounting Literature," Vol.16, pp. 28-85, 1997.

12. Feather, N., and R. Volkmer, "Preference for Situations Involving Effort, Time Pressure, and Feedback in Relation to Type A Behavior, Locus of Control, and Test Anxiety," Journal of Personality and Social Psychology," Vol. 55, No. 2, pp. 266-271, 1988.

13. Glover, S.M., "The Influence of Time Pressure and Accountability on Auditors' Processing of Nondiagnostic Information,” Journal of Accounting Research, pp. 213-226, autumn 1997.

14. Haskins, M., A. Baglioni, and C. Cooper, "An Investigation of the Sources, Moderators, and Psychological Symptoms of Stress among Audit Seniors," Contemporary Accounting Research, Vol. 6, No. 2, pp. 261- 
$385,1990$.

15. Houston, R., "The Effects of Fee Pressure and Client Risk on Audit Seniors' Time Budget Decisions," Auditing: A Journal of Practice and Theory, Vol. 18, No. 2, pp. 70-86, 1999.

16. Kelley, T., and S. E. Seiler, "Auditor Stress and Time Budgets," The CPA Journal, pp.24-34, December 1982.

17. Kelley, T., and L. Margheim, "The Impact of Time Budget Pressure, Personality, and Leadership Variables on Dysfunctional Auditor Behavior," Auditing: A Journal of Practice and Theory, pp. 21-42, Spring 1990.

18. Kelley, T., L. Margheim, and D. Pattison, "Survey on the Differential Effects of Time Deadline Pressure Versus Time Budget Pressure on Auditor Behavior," The Journal of Applied Business Research, Vol.15, No. 4, pp. 117-128, Spring 1999.

19. Klein, M., "Détente: House, Senate Reach Accord on Accounting Reform Legislation," Accounting Today, Vol. 16, No. 14, p. 1, August 1-18, 2002.

20. Lightner, S. M., S. J. Adams, and K. M. Lightner, "The Influence of Situational, Ethical, and Expectancy Theory Variables on Accountants' Underreporting Behavior," Auditing: A Journal of Practice \& Theory, Vol. 2, No. 1, pp. 1-12, 1982.

21. Malone, C., and R. Roberts, "Factors Associated with the Incidence of Reduced Audit Quality Behaviors," Auditing: A Journal of Practice and Theory, Vol.15, pp. 47-64, Fall 1996.

22. Margheim, L., and K. Pany, "Quality Control, Premature Signoff, and Underreporting to Time: Some Empirical Findings," Auditing: A Journal of Practice and Theory, pp. 50-63, Spring 1986.

23. McDaniel, L., "The Effects of Time Pressure and Audit Program Structure," Journal of Accounting Research, Vol. 28, No.2, pp. 267-285, 1990

24. Otley, D.T., and B.J. Pierce, "The Operation of Control Systems in Large Audit Firms," Auditing: A Journal of Practice and Theory, Vol. 15, pp. 65-84, Fall 1996.

25. Raghunathan, B., "Premature Signing-off of Audit Procedures: An Analysis," Accounting Horizons, pp. 7179, June 1991.

26. Rhode, J.G., "Survey on the Influence of Selected Aspects of the Auditor's Work Environment on Professional Performance of Certified Public Accountants," Issued as the Independent Auditor's Work Environment: A Survey, New York: American Institute of Certified Public Accountants, 1978.

27. Solomon, I., and C. Brown, "Auditors' Judgments and Decisions Under Time Pressure: An Illustration and Agenda for Research," Proceedings of the 1992 Deloitte \& Touche/University of Kansas Symposium on Auditing Problems, pp.73-98, 1992.

28. Waggoner, J., and J. Cashell, "The Impact of Time Pressure on Auditors' Performance," The Ohio CPA, pp. 27 -32, January-February 1991.

Table 1 ANOVA Results on Expected Stress Levels

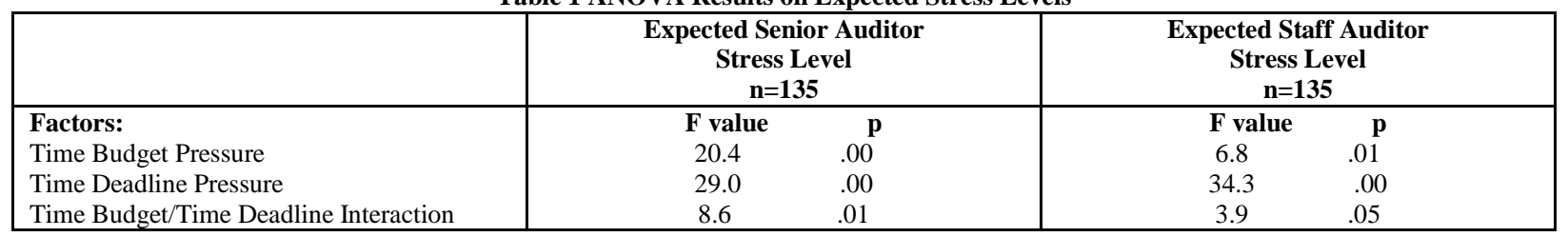


Table 2 Expected Hypothetical Senior and Staff Auditor Subjective Stress Level Means

\begin{tabular}{|c|c|c|c|c|c|c|}
\hline & $\begin{array}{c}\text { Case 1 } \\
\text { Moderate Budget/ } \\
\text { Moderate Deadline } \\
\text { Pressure } \\
\mathbf{n}=\mathbf{3 2}\end{array}$ & $\begin{array}{c}\text { Case 2 } \\
\text { Moderate Budget/ } \\
\text { High Deadline } \\
\text { Pressure } \\
\text { n=31 }\end{array}$ & $\begin{array}{c}\text { Case 3 } \\
\text { High Budget/ } \\
\text { Moderate Deadline } \\
\text { Pressure } \\
\mathbf{n}=\mathbf{3 7}\end{array}$ & $\begin{array}{c}\text { Case 4 } \\
\text { High Budget/ } \\
\text { High Deadline } \\
\text { Pressure } \\
\text { n=35 }\end{array}$ & $\begin{array}{l}\text { Main Ef } \\
\text { Moderate } \\
\text { B } n=63 \\
\text { D } n=69\end{array}$ & $\begin{array}{l}\text { ects } \\
\text { High } \\
n=72 \\
n=66\end{array}$ \\
\hline Senior Auditor Stress Means & 4.2 & 5.5 & 5.2 & 5.8 & $\begin{array}{ll}\text { B } & 4.9 \\
\text { D } & 4.8\end{array}$ & $\begin{array}{l}5.6 * * \\
5.7 * *\end{array}$ \\
\hline Staff Auditor Stress Means & 3.5 & 4.7 & 4.3 & 4.8 & $\begin{array}{ll}\text { B } & 4.1 \\
\text { D } & 3.9\end{array}$ & $\begin{array}{l}4.5 * * \\
4.8 * *\end{array}$ \\
\hline
\end{tabular}

$\mathrm{B}=$ Time budget pressure; $\mathrm{D}=$ Time deadline pressure.

** Significant at $\mathrm{p}<.05$.

Note: Means were computed based upon respondent expectations of the stress levels that would be perceived by the hypothetical senior auditor and staff auditor described in the case. Both seniors and staff auditors served as respondents. Responses were based on the following seven point scale:

$1=$ No stress; $2=$ Very low stress; $3=$ Low stress; $4=$ Moderate stress; $5=$ High stress; $6=$ Very high stress; $7=$ Extreme stress

Table 3 MANOVA Results on Expected Senior and Staff Organizational Behavior Measures

\begin{tabular}{|l|cc|cc|}
\hline & $\begin{array}{c}\text { Expected Senior Auditor Organizational } \\
\text { Behavior Measures } \\
\text { n=61 }\end{array}$ & $\begin{array}{c}\text { Expected Staff Auditor } \\
\text { Organizational Behavior Measures } \\
\text { n=135 }\end{array}$ \\
\hline Factors: & F value & $\mathbf{p}$ & F value & $\mathbf{p}$ \\
Time Budget Pressure & 2.4 & .03 & 3.4 & .00 \\
Time Deadline Pressure & $3.6 \quad .00$ & 3.4 & .00 \\
Time Budget/Time Deadline Interaction & 1.4 & $\mathrm{~ns}$ & 1.2 & $\mathrm{~ns}$ \\
\hline
\end{tabular}

ns = nonsignificant.

Note: $\quad$ See Table 4 for a list of the eight specific organizational behavior measures examined.

Table 4 Expected Senior Auditor Organizational Behavior Measures Means

\begin{tabular}{|c|c|c|c|c|c|}
\hline & $\begin{array}{c}\text { Case 1 } \\
\text { Moderate } \\
\text { Budget/Moderate } \\
\text { Deadline Pressure } \\
\text { n=19 } \\
\end{array}$ & $\begin{array}{c}\text { Case 2 } \\
\text { Moderate } \\
\text { Budget/High } \\
\text { Deadline Pressure } \\
\text { n=15 }\end{array}$ & $\begin{array}{c}\text { Case 3 } \\
\text { High } \\
\text { Budget/Moderate } \\
\text { Deadline Pressure } \\
\text { n=14 } \\
\end{array}$ & $\begin{array}{c}\text { Case } 4 \\
\text { High Budget/ } \\
\text { High Deadline } \\
\text { Pressure } \\
\text { n=13 }\end{array}$ & \begin{tabular}{lc}
\multicolumn{2}{c}{ Main Effects } \\
Moderate & High \\
B $\mathbf{n = 3 4}$ & $\mathbf{n = 2 7}$ \\
D $\mathbf{n = 3 3}$ & $\mathbf{n}=\mathbf{2 8}$
\end{tabular} \\
\hline \multicolumn{6}{|c|}{ Senior Auditor Job Performance Measures: } \\
\hline High Effectiveness Probability & $87 \%$ & $76 \%$ & $74 \%$ & $48 \%$ & $\begin{array}{lll}\text { B } & 82 \% & 61 \% * * \\
\text { D } & 80 \% & 60 \% * *\end{array}$ \\
\hline High Efficiency Probability & $62 \%$ & $83 \%$ & $73 \%$ & $84 \%$ & $\begin{array}{lll}\mathrm{B} & 73 & 80 \% \\
\mathrm{D} & 67 \% & 83 \% * *\end{array}$ \\
\hline \multicolumn{6}{|c|}{ Senior Auditor Dysfunctional Behavior Measures: } \\
\hline $\begin{array}{l}\text { Underreporting of Time } \\
\text { Probability }\end{array}$ & $42 \%$ & $31 \%$ & $68 \%$ & $52 \%$ & $\begin{array}{l}\text { B } 37 \% 60 \% * * \\
\text { D } 55 \% 43 \%\end{array}$ \\
\hline $\begin{array}{l}\text { Premature Signoff on Audit Steps } \\
\text { Probability }\end{array}$ & $24 \%$ & $38 \%$ & $36 \%$ & $44 \%$ & $\begin{array}{ll}\text { B } & 29 \% 40 \% \\
\text { D } & 29 \% 42 \%\end{array}$ \\
\hline $\begin{array}{l}\text { Superficial Review of Documents } \\
\text { Probability }\end{array}$ & $26 \%$ & $47 \%$ & $50 \%$ & $60 \%$ & $\begin{array}{lll}\mathrm{B} & 33 \% & 54 \% * * \\
\mathrm{D} & 35 \% & 55 \% * *\end{array}$ \\
\hline $\begin{array}{l}\text { Performing Less Work than } \\
\text { Normally Considered Reasonable } \\
\text { Probability }\end{array}$ & $27 \%$ & $45 \%$ & $60 \%$ & $50 \%$ & $\begin{array}{l}\text { B } 33 \% 54 \% * * \\
\text { D } 41 \% \quad 48 \%\end{array}$ \\
\hline $\begin{array}{l}\text { Inadequate Accounting Principles } \\
\text { Research Probability }\end{array}$ & $25 \%$ & $37 \%$ & $51 \%$ & $50 \%$ & $\begin{array}{l}\text { B } 30 \% 51 \% * * \\
\text { D } 37 \% 45 \%\end{array}$ \\
\hline $\begin{array}{l}\text { Accepting Weak Client } \\
\text { Explanation Probability }\end{array}$ & $23 \%$ & $48 \%$ & $55 \%$ & $61 \%$ & $\begin{array}{lll}\mathrm{B} & 34 & 59 \% * * \\
\mathrm{D} & 39 \% & 57 \% * *\end{array}$ \\
\hline
\end{tabular}

$\mathrm{B}=$ Time budget pressure; $\mathrm{D}=$ Time deadline pressure.

** Significant at $\mathrm{p}<.05$.

Note 1: Means are probabilities that the senior auditor in the case would engage or exhibit the listed behavior. Only senior auditors served as respondents and were asked to provide a probability from $0 \%$ to $100 \%$ that the behavior would occur.

Note 2: The time budget/time deadline interactions were not significant in any of the eight individual ANOVAs. 
Table 5 Expected Staff Auditor Organizational Behavior Measures Means

\begin{tabular}{|c|c|c|c|c|c|}
\hline & $\begin{array}{c}\text { Case 1 } \\
\text { Moderate Budget/ } \\
\text { Moderate Deadline } \\
\text { Pressure } \\
\text { n=32 }\end{array}$ & $\begin{array}{c}\text { Case 2 } \\
\text { Moderate } \\
\text { Budget/ } \\
\text { High Deadline } \\
\text { Pressure } \\
\text { n=31 }\end{array}$ & $\begin{array}{c}\text { Case 3 } \\
\text { High Budget/ } \\
\text { Moderate Deadline } \\
\text { Pressure } \\
\text { n=37 }\end{array}$ & $\begin{array}{c}\text { Case } 4 \\
\text { High Budget/ } \\
\text { High Deadline } \\
\text { Pressure } \\
\text { n=35 }\end{array}$ & \begin{tabular}{cc}
\multicolumn{2}{c}{ Main Effects } \\
Moderate & High \\
B $n=63$ & $n=72$ \\
D $n=69$ & $n=66$
\end{tabular} \\
\hline \multicolumn{6}{|c|}{ Staff Auditor Job Performance Measures: } \\
\hline High Effectiveness Probability & $78 \%$ & $68 \%$ & $69 \%$ & $60 \%$ & $\begin{array}{l}\text { B } 74 \% 64 \% * * \\
\text { D } 74 \quad 64 \% * *\end{array}$ \\
\hline High Efficiency Probability & $66 \%$ & $70 \%$ & $64 \%$ & $75 \%$ & $\begin{array}{l}\text { B } 67 \% 70 \% \\
\text { D } 6572 \% * *\end{array}$ \\
\hline \multicolumn{6}{|c|}{ Staff Auditor Dysfunctional Behavior Measures: } \\
\hline Underreporting of Time Probability & $34 \%$ & $32 \%$ & $40 \%$ & $51 \%$ & $\begin{array}{l}\text { B 33\% 46\% ** } \\
\text { D } 37 \% 42 \%\end{array}$ \\
\hline $\begin{array}{l}\text { Premature Signoff on Audit Steps } \\
\text { Probability }\end{array}$ & $26 \%$ & $39 \%$ & $31 \%$ & $42 \%$ & $\begin{array}{ll}\text { B } & 31 \% 37 \% \\
\text { D } & 29 \% 40 \% * *\end{array}$ \\
\hline $\begin{array}{l}\text { Superficial Review of Document } \\
\text { Probability }\end{array}$ & $27 \%$ & $47 \%$ & $41 \%$ & $61 \%$ & $\begin{array}{ll}\mathrm{B} & 35 \% 51 \% * * \\
\mathrm{D} & 34 \% 54 \% * *\end{array}$ \\
\hline $\begin{array}{l}\text { Performing Less Work than } \\
\text { Normally Considered Reasonable } \\
\text { Probability }\end{array}$ & $25 \%$ & $42 \%$ & $37 \%$ & $50 \%$ & $\begin{array}{ll}\text { B } & 33 \% 43 \% * * \\
\text { D } & 31 \% 46 \% * *\end{array}$ \\
\hline $\begin{array}{l}\text { Inadequate Accounting Principles } \\
\text { Research Probability }\end{array}$ & $38 \%$ & $49 \%$ & $52 \%$ & $60 \%$ & $\begin{array}{ll}\mathrm{B} & 43 \% 56 \% * * \\
\mathrm{D} & 45 \% 55 \% * *\end{array}$ \\
\hline $\begin{array}{l}\text { Accepting Weak Client } \\
\text { Explanation Probability }\end{array}$ & $39 \%$ & $60 \%$ & $55 \%$ & $60 \%$ & $\begin{array}{|ll|}\mathrm{B} & 48 \% 58 \% * \\
\mathrm{D} & 47 \% 60 \% * * \\
\end{array}$ \\
\hline
\end{tabular}

$\mathrm{B}=$ Time budget pressure; $\mathrm{D}=$ Time deadline pressure; $* *$ Significant at $\mathrm{p}<.05 ; *$ Significant at $\mathrm{p}<.10$.

Note 1: $\quad$ Means are based on the respondent probabilities that the staff auditor in the case would engage or exhibit the listed behavior. Both senior and staff auditors served as respondents who were asked to provide a probability from $0 \%$ to $100 \%$ that the behavior would occur.

Note 2: The time budget/time deadline interactions were not significant in any of the eight individual ANOVAs.

Table 6 MANOVA Results on Expected Senior and Staff Cognitive Problems

\begin{tabular}{|c|c|c|}
\hline & $\begin{array}{c}\begin{array}{c}\text { Expected Senior Auditor Cognitive } \\
\text { Problems } \\
n=61\end{array} \\
\end{array}$ & $\begin{array}{l}\text { Expected Staff Auditor Cognitive Problems } \\
\qquad=135\end{array}$ \\
\hline Factors: & $\begin{array}{ll}\text { F value } & \text { p } \\
\end{array}$ & F value \\
\hline Time Budget Pressure & 3.2 & 4.6 \\
\hline Time Deadline Pressure & 1.5 & 6.0 \\
\hline Time Budget/Time Deadline Interaction & $\mathrm{ns}$ & 1.1 \\
\hline
\end{tabular}

ns = nonsignificant; Note: See Table 7 for a list of the three cognitive problem measures examined.

Table 7 Expected Senior Auditor Cognitive Problems Means

\begin{tabular}{|c|c|c|c|c|c|c|}
\hline & $\begin{array}{c}\text { Case 1 } \\
\text { Moderate } \\
\text { Budget/ } \\
\text { Moderate } \\
\text { Deadline } \\
\text { Pressure } \\
\text { n=19 }\end{array}$ & $\begin{array}{c}\text { Case 2 } \\
\text { Moderate } \\
\text { Budget/ } \\
\text { High Deadline } \\
\text { Pressure } \\
\text { n=15 }\end{array}$ & $\begin{array}{c}\text { Case 3 } \\
\text { High Budget/ } \\
\text { Moderate } \\
\text { Deadline } \\
\text { Pressure } \\
\text { n=14 }\end{array}$ & $\begin{array}{c}\text { Case } 4 \\
\text { High Budget/ } \\
\text { High Deadline } \\
\text { Pressure } \\
\text { n=13 }\end{array}$ & $\begin{array}{l}\text { Main Ef } \\
\text { Moderate } \\
\text { B } n=34 \\
\text { D } n=33\end{array}$ & $\begin{array}{c}\text { High } \\
\mathbf{n}=27 \\
\mathbf{n}=28\end{array}$ \\
\hline Careless Mistake Probability & $23 \%$ & $45 \%$ & $48 \%$ & $54 \%$ & $\begin{array}{ll}\text { B } & 34 \% \\
\text { D } & 37 \%\end{array}$ & $\begin{array}{l}52 \% * * \\
52 \% * *\end{array}$ \\
\hline $\begin{array}{l}\text { Mentally Block Out Information } \\
\text { Suggesting Need for Additional Audit } \\
\text { Work Probability }\end{array}$ & $24 \%$ & $42 \%$ & $49 \%$ & $47 \%$ & $\begin{array}{ll}\text { B } & 32 \% \\
\text { D } & 37 \%\end{array}$ & $\begin{array}{l}49 \% \\
45 \%\end{array}$ \\
\hline $\begin{array}{l}\text { Difficulty Differentiating Between } \\
\text { Serious and Trivial Errors Probability }\end{array}$ & $14 \%$ & $26 \%$ & $37 \%$ & $40 \%$ & $\begin{array}{ll}\text { B } & 17 \% \\
\text { D } & 23 \%\end{array}$ & $\begin{array}{l}38 \% * * \\
34 \%\end{array}$ \\
\hline
\end{tabular}

$\mathrm{B}=$ Time budget pressure; $\mathrm{D}=$ Time deadline pressure; ** Significant at $\mathrm{p}<.05$; See Notes 1 and 2 on Table 4 . 
Table 8 Expected Staff Auditor Cognitive Problems Means

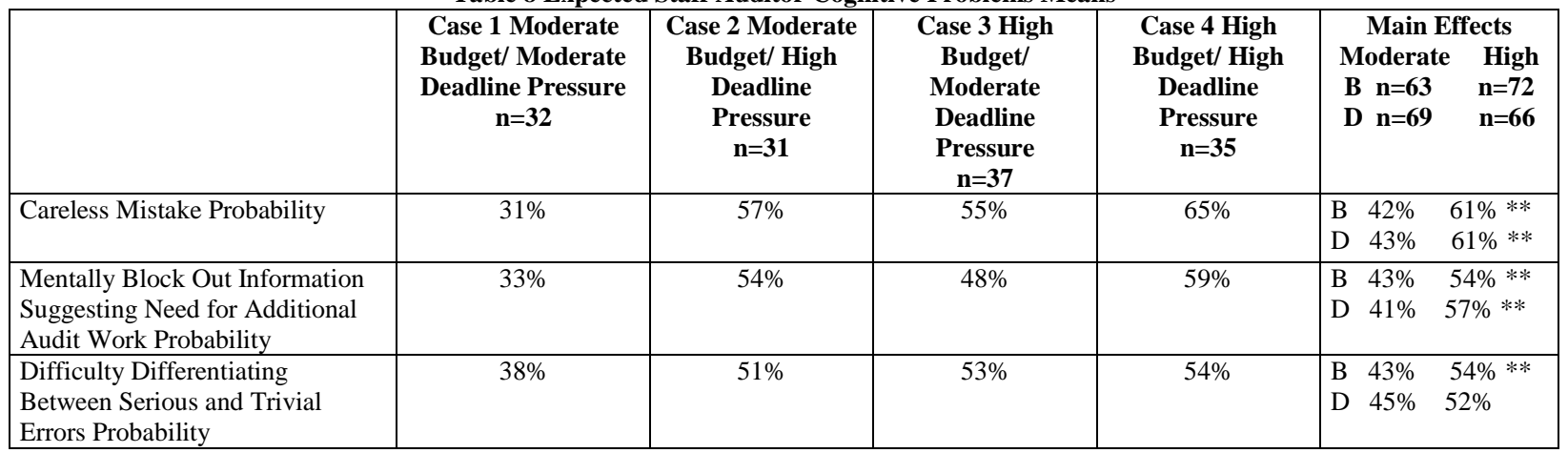

$\mathrm{B}=$ Time budget pressure; $\mathrm{D}=$ Time deadline pressure.

** Significant at $\mathrm{p}<.05$.

See Notes 1 and 2 on Table 5.

Notes 
Notes 